\title{
Małgorzata Bombol
}

\section{Zarządzanie finansami}

\section{przez zamożnych Polaków a procesy naśladownictwa w konsumpcji}

Zachowania finansowe należą do obszaru najistotniejszych codziennych zachowań konsumenckich. Na poziomie analiz statystycznych i makroekonomicznych wszystko wydaje się z pozoru proste i kwantyfikowalne. Poziom dochodu, ceny dóbr i usług konsumpcyjnych, style zachowań i potrzeby, to tylko kilka $\mathrm{z}$ wielu elementów, które oddziałują na konsumentów w procesach gospodarowania pieniędzmi.

Jak zauważa A. Jurnham [1996], z ekonomicznego punktu widzenia, różnice indywidualne w zakresie postaw wobec pieniędzy to wariancja btędu, natomiast w psychologii ekonomicznej traktowane są one jako istotne zmienne wpływające na ludzkie zachowania. Ponadto, w literaturze [Shafer, 2000] nie ma zgody co do tego, jak nazywać kwestię różnic indywidualnych w zakresie rozumienia $\mathrm{i}$ traktowania pieniędzy. Najczęściej używa się wprost pojęcia postawa wobec pieniędzy [Shafer, 2000] lub też w tym samym znaczeniu - określenia przekonania $i$ zachowania odnośnie pieniędzy [Hayhoe, Leach, Turner, 1999]. Jednakże, spojrzenie indywidualne (jednostkowe) komplikuje możliwości oceny zachowań konsumenckich w sferze pieniędzy. Osoby o bardzo zbliżonym poziomie dochodu i znajdujące się w podobnych uwarunkowaniach życiowych zachowują się zupełnie inaczej: jedna wydaje pieniądze bez problemu, czasem nawet bezrefleksyjnie, druga zaś oszczędza, a wydatki sprawiają jej przykrość [Maison, 2013]. Należy podkreślić, że to właśnie różnice indywidualne i wynikające z nich ogólne podejście do życia, poziom optymizmu, poczucia kontroli i sprawczości wobec losu, sam stosunek do pieniędzy i podejścia do zarządzania nimi, świadczą o prawdziwym obliczu jednostki w świecie finansów osobistych.

W różnorodnych analizach zachowań finansowych Polaków bardzo często podkreśla się, że w naszym społeczeństwie brakuje wypracowanych modeli zachowań finansowych, które propagowałyby większą skłonność do oszczędzania i budowania swojego kapitału. Nie jest to związane tylko i wyłącznie z zabezpieczeniem materialnym na okres emerytury, ale chodzi o zbudowanie powszechnej „mody” odraczania gratyfikacji jaką jest przyjemność konsumpcji. Po prawie trzech dekadach gospodarki wolnorynkowej, obserwujemy wiele typowych zachowań społeczeństwa konsumpcyjnego - poszukiwania kolejnych produktów i usług zaspokajających nowe potrzeby klientów, koncentrację na hedonizmie konsumenckim, oczekiwania klientów na kolejne nowości i rozszerzanie dotychczasowych funkcjonalności produktów i usług. Rynek nieustannie zaskakuje, ale i angażuje percepcję nabywców - co niesie za sobą wzrost wydatków 
konsumpcyjnych. Obserwowany prymat przyjemności nad pragmatyzmem odnajdujemy w danych dotyczących oszczędności osobistych, budowania zasobności materialnej i majątku. Niepokojące $\mathrm{z}$ makroekonomicznego punktu widzenia dane skłaniają do refleksji, że dotychczasowe zachęty do podejmowania samodzielnych działań w sferze finansów osobistych okazały się nieskuteczne. Stąd też, jako cel niniejszego opracowania przyjęto wykorzystanie modelu naśladownictwa społecznego w upowszechnianiu wiedzy na temat możliwości budowania kapitału na przyszłość. Jako grupę wzorcotwórczą uznano konsumentów należących do segmentu affluent - osoby o dochodach netto powyżej 7500 zł miesięcznie.

\section{Mechanizm}

\section{naśladownictwa społecznego}

Jednostki podlegają w swych zachowaniach wpływowi innych ludzi. Są to przede wszystkim wpływy interpersonalne, które kształtując zachowanie konsumenta, prowadzą do wytworzenia się mechanizmu naśladownictwa. Społeczeństwo ma obecnie ogromny wpływ na działanie indywidualnej jednostki, a efekt naśladownictwa można $\mathrm{z}$ całą pewnością zaliczyć do prawidłowości oddziałujących bezpośrednio na konsumentów. Wyjątkowość tego czynnika wynika $\mathrm{z}$ faktu, iż odnosi się on do wszystkich konsumentów bez względu na płeć, wiek, wykształcenie czy poziom dochodów [Burgiel, 2005]. Zjawisko naśladownictwa dotyczy wszystkich grup konsumentów, gdyż poniekąd każdy człowiek (w mniejszym bądź większym stopniu) podlega wpływowi innych ludzi [Wyrwicka, 2001].

Procesy naśladownictwa oparte są na wrodzonym bezwarunkowym odruchu, który w perspektywie zachowań konsumenckich staje się instrumentalnym odruchem nawiązującym do procesu uczenia się (zachowania i działania wzorowane są na innych). Jednostki pragną upodob- nić się do innych, gdyż w ich oczach to właśnie widoczna większość (grupa, społeczeństwo) reprezentuje prawdopodobnie najwłaściwsze wzorce. Zachowanie naśladowcze występuje, gdy „przypomina zachowanie innej osoby, w stosunku do której jest reakcją" [Newcomb, Turner, Converse, 1965], a owe zachowanie pozwala człowiekowi osiągnąć istotne cele (zyskanie akceptacji, zwrócenie uwagi, wyrażanie swojej postawy itd.). Powodami występowania naśladownictwa są dwa przeciwstawne dążenia - motyw wyróżnienia oraz upodobnienia. Naśladownictwo jest uwarunkowane biologicznie, związane jest z fizycznymi ograniczeniami ludzkiego ciała i umysłu, chroni też przed nadmiarem informacji. Jest podstawowym środkiem adaptacyjnym człowieka, który pomaga mu w procesie socjalizacji. Wykorzystując (naśladując) wiedzę i narzędzia innych ludzi, możemy szybko i efektywnie rozwiązywać własne problemy, a dodatkowo, przez naśladowanie ludzi z danej grupy społecznej, zdobywamy akceptację i identyfikację [Burgiel, 2005].

Powyższe procesy, szeroko omawiane w socjologii i psychologii rozwojowej człowie$\mathrm{ka}$, mają zastosowanie także w badaniu zachowań konsumentów. Umiejętność naśladowania ma każdy człowiek, lecz skłonność do tego zachowania zależy od indywidualnych predyspozycji psychospołecznych, umiejętności podejmowania decyzji na podstawie własnej wiedzy i kryteriów.

Naśladownictwo społeczne jest wynikiem interakcji ludzi, będących wpływem interpersonalnym (osobistym), opisanym przez R. Mertona jako: relacja, która oddziatuje na przyszte zachowania lub postawy uczestników interakcji i zmienia je $w$ takim stopniu, iż różnia się one od tych, jakie przewidywaliby uczestnicy interakcji, gdyby do niej nie doszto [Merton, 1957]. To, w jakim stopniu człowiek czerpie inspirację swoich zachowań od innych ludzi, zależy w dużym stopniu od stopnia jego podatności na wpływy innych. Podatność kon- 
sumenta na wptywy interpersonalne to (...) potrzeba konsumenta, aby identyfikować sie ze znaczacymi osobami lub poprawić wtasny wizerunek $w$ ich oczach. Przejawia sie ona nabywaniem i używaniem określonych marek produktów, dostosowywaniem swoich decyzji zakupowych do oczekiwań tych osób, zdobywaniem wiedzy o produktach od konkretnych osób i na podstawie ich obserwacji [Bearden, Netemeyer, Teel, 1989].

W nawiązaniu do procesów konsumpcji została skonstruowana teoria J.S. Duesenberry'ego [1952]. Konsumpcja poprzedzona jest zwykle wydatkowaniem pieniędzy. Tak jak większość innych działań, w które angażują się ludzie, jest uwarunkowana kulturowo i dostarcza wyboru możliwych opcji zachowania. Mając odpowiednie dane, można $\mathrm{z}$ dużym prawdopodobieństwem z góry określić większość konsumenckich posunięć, zachowań czy wyborów danej jednostki, a także całych grup społecznych.

Należy zaznaczyć, że jednym z głównych celów współczesnych społeczności jest stałe podwyższanie swojego standardu i jakości życia, co wywodzi się z charakteru naszej kultury. Ludzie nieustannie porównują się do innych, a podejmując codzienne decyzje konsumenckie, dążą do bardziej wygodnego, komfortowego życia. Konflikt pomiędzy chęcią posiadania dóbr wysokiej jakości a potrzebą oszczędzania jest nieodzowny. Jednak zwiększona częstotliwość kontaktu z konsumpcją osób zamożniejszych od jednostki, a co za tym idzie z dobrami wyższej jakości, staje się przyczyną do niezadowolenia $\mathrm{z}$ obecnie konsumowanych dóbr i zarazem impulsem do zaprzestania oszczędności i zwiększenia wydatków na lepsze produkty. J.S Duesenberry nazywa ten proces efektem demonstracji.

Jak zauważa T. Szlendak, mamy do czynienia ze zmianami zachodzącymi $\mathrm{w}$ naśladownictwie społecznym, co można dobrze zaobserwować na przykładzie mody [Szlendak, Pietrowicz, 2007]. Ist- nieje mianowicie zjawisko dwutorowości mody, a w konsekwencji przenikania wzorców konsumpcji. Tradycyjny, zauważony przez J. Duesenberry'ego, tor przenikania wzorców od wyższej warstwy społecznej do niższej nabiera nowego wydźwięku. Tak zwany cykl repetycji (różnicowania) klas w tworzeniu wzorców konsumpcji polega na następującej zasadzie:

- klasa wyższa kreuje i wdraża nowe wzorce przedmiotów i stylów konsumpcji, wysoce kosztownych, co pozwala na stworzenie linii demarkacyjnej od pozostałych członków społeczeństwa, których na te formy konsumpcji nie stać;

- klasa niższa (jak nazywa T. Szlendak - ludowa) podpatruje elity zarówno w miejscach swej pracy, jak i w przestrzeni publicznej, naśladuje wzorce, stosując do ich wykonania tańsze materiały;

- w momencie upowszechnienia wzorców klasy wyższej na szeroką skalę, następuje moment odcięcia od mas konsumentów i wprowadzenie nowych stylów zachowań i przedmiotów sygnalizujących prestiż i status.

Model naśladownictwa społecznego może być przydatny nie tylko w obserwacji zmieniającej się mody. Przy wyodrębnieniu w miarę homogenicznej grupy wzorcotwórczej oraz jej systematycznych badaniach, można przewidywać transmisję określonych zachowań do innych grup społecznych, które takich zachowań nie przejawiają.

\section{Marzenia finansowe Polaków}

Odnosząc się do sfery finansów osobistych, dla znakomitej większości Polaków głównym problemem jest zbyt niski poziom oszczędzania i myślenia o swej bezpiecznej materialnej przyszłości. W reprezentatywnych badaniach sondażowych, przeprowadzonych przez autorkę wraz $\mathrm{z}$ Deutsche Bank (Marzenia finansowe Po- 
laków, badanie IBRiS dla Deutsche Bank na losowo-kwotowej próbie $\mathrm{N}=1100$ dorosłych Polaków, listopad 2016) ujawniono, że Polacy marzą głównie o tym, by nie musieć zastanawiać się, czy wystarczy im pieniędzy na niezbędne wydatki - stwierdziło tak 38,9 proc. badanych (rys. 1). Na drugim miejscu znalazło się marzenie o posiadaniu kapitału, który daje poczucie bezpieczeństwa - taką odpowiedź dało 37,9 proc. ankietowanych. Polacy pragną także, by zakupy dóbr materialnych nie były dla nich problemem, w wymarzonym scenariuszu, żeby nie musieli na nie oszczędzać - takiej odpowiedzi udzieliło 34,3 proc. respondentów. Analizując wyniki badania Deutsche Bank, w podziale na grupy wiekowe można zauważyć, że osoby dopiero wchodzące $\mathrm{w}$ dorosłość myślą o swoich finansach inaczej niż osoby starsze. Najczęstszym marzeniem młodych jest kupno mieszkania bez potrzeby zaciągania kredytu - takie pragnienie ma aż 66 proc. osób w wieku 18-24 lata. Co ciekawe, dla tej grupy wiekowej ważne jest także oszczędzanie. To właśnie młode osoby najczęściej myślą o tym by zgromadzić majątek, który będą mogli przekazać dzieciom - tę odpowiedź wskazało aż 2/3 ankietowanych osób w tym wieku. Nieco starsi ankietowani (35-44 lata) skupiają się częściej na tym, aby zakupy dóbr materialnych nie były dla nich problemem (48 proc.). Jednocześnie, prawie połowa $\mathrm{z}$ nich chciałaby nie martwić się spłatami swoich zobowiązań. Z wiekiem rośnie jednak obawa o to, czy pieniędzy wystarczy na wszystkie potrzebne wydatki - wskazało ją aż 45 proc. ankietowanych powyżej 65. roku życia.

W przytoczonych badaniach ujawniono „trójpodział” marzeń finansowych Polaków. Pierwsza grupa to osoby dążące do budowania solidnych podstaw swojego majątku (dla siebie i dla swoich dzieci). W związku z tym, marzenia o zbudowaniu kapitału będącego źródłem poczucia bezpieczeństwa, a także dobrostanu psychicznego, są jak najbardziej naturalne. To także osoby akceptujące odroczenie gratyfikacji na przyszłość, rezygnujące z ulotnej przyjemności konsumpcji. Oczywiście, na ten komfort mogą pozwolić sobie ci, którzy po pierwsze nie mają problemów z zaspokajaniem bieżących potrzeb i mają większy fundusz swobodnej decyzji. Są też osoby posiadające aspiracje konsumpcyjne lecz niewystarczający poziom dochodów i posiłkujące się finansowaniem zewnętrznym. Stąd dla nich, marzenia o niepłaceniu rat za samochód czy mieszkanie są jak najbardziej oczywiste. Ostatnia grupa to osoby pragnące, by finanse nie spędzały im snu z powiek. Tak zdefiniowane marzenia wskazują na deficyt poczucia bezpieczeństwa i raczej krótkookresową orientację w gospodarowaniu budżetem.

Rysunek 1 Marzenia finansowe Polaków z dochodem netto powyżej 5000 zł

miesięcznie na osobę (dane w \%, można było wybrać trzy odpowiedzi)

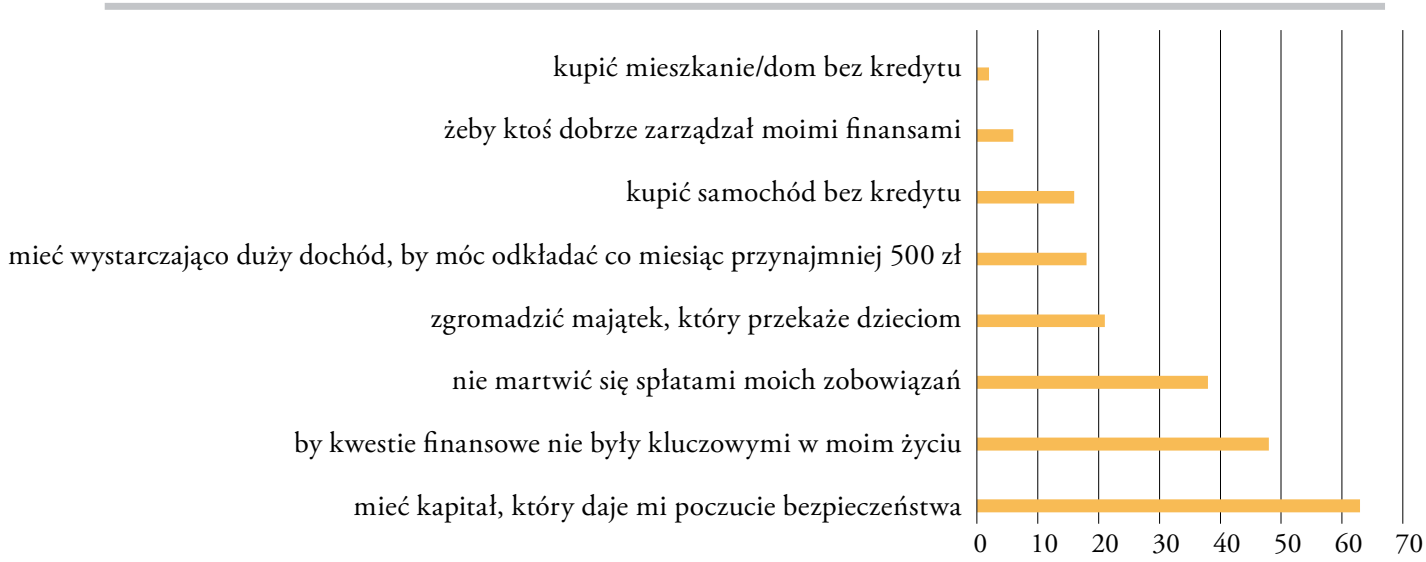

Źródło: Marzenia finansowe Polaków, badanie IBRiS dla Deutche Bank na losowo-kwotowej próbie N=1100 dorosłych Polaków, listopad 2016. 
Przyjmując powyższe badania jako punkt odniesienia, za cel artykułu uznano diagnozę zachowań finansowych zamożnych Polaków i próbę odpowiedzi, czy mają one szansę stać się wzorcotwórcze dla pozostałych grup społecznych.

\section{Zamożni Polacy w badaniach empirycznych}

Zamożny Polak - czyli kto? Przyjmując za punkt wyjścia dane NBP [NBP, 2017], warto posłużyć się wielkością majątku netto, odzwierciedlającą różnicę między wartością aktywów i wartością zobowiązań gospodarstwa domowego. O wartości majątku netto polskich gospodarstw domowych decydują przede wszystkim aktywa rzeczowe zgromadzone przez gospodarstwo domowe, w tym przede wszystkim: główne miejsce zamieszkania (265,4 tys. zł), inne nieruchomości (119,8 tys. zł) oraz zasób majątku wynikającego z prowadzenia działalności gospodarczej (144,9 tys. zł). Finansowe składniki majątku mają relatywnie mniejsze znaczenie i wynoszą ogółem przeciętnie 15,3 tys. zł. Zadłużenie, o ile występuje, jest przeciętnie stosunkowo niewielkie (10,0 tys. zł). Ponadto, majątek netto jest nierównomiernie rozłożony $\mathrm{w}$ populacji gospodarstw domowych, a jego silną koncentrację obserwujemy w zbiorowości gospodarstw najbardziej majętnych. Dziesięć procent najbardziej zasobnych gospodarstw domowych posiada około 41 proc. całkowitego majątku netto. Podczas gdy majątek 20 proc. najmniej zasobnych gospodarstw to jedynie niewielka część (1 proc.) majątku wszystkich gospodarstw domowych. Jeśli chodzi o sytuację Polski na tle innych krajów Unii Europejskiej, mediana majątku netto przeciętnego polskiego gospodarstwa domowego (wynosząca 60,6 tys. euro) to 58 proc. mediany majątku netto przeciętnego gospodarstwa domowego w strefie euro (104, 1 tys. euro) Najwyższym zasobem majątku netto, przypadającym na gospodarstwo domowe w strefie euro, odznaczają się Luksemburg (437,5 tys. euro), Belgia (217,9 tys. euro) i Malta (209,9 tys. euro). Oznacza to, że polskie gospodarstwa domowe należą do umiarkowanie majętnych na tle krajów strefy euro. Jak podano w raporcie NBP [NBP, 2017, s. 34], podobnie jest w przypadku pozostałych krajów Europy Środkowo-Wschodniej, jak Słowenia (80,4 tys. euro), Słowacja (50,3 tys. euro), Estonia (43,5 tys. euro), Węgry (26,2 tys. euro) czy Łotwa (14,2 tys. euro). Spośród krajów Europy Zachodniej, majątkiem netto zbliżonym do obserwowanego (mediana) w Polsce dysponują gospodarstwa domowe w Grecji (65,1 tys. euro), Portugalii (71,2 tys. euro), a także Niemcy (60,8 tys. euro) i Holandia (82 tys. euro). Ważną cechą charakterystyczną majątku gospodarstw domowych w Polsce jest fakt, że na tle strefy euro dominują u nas elementy rzeczowe - głównie miejsce zamieszkania. Aktywa finansowe mają w przypadku polskich gospodarstw domowych mniejsze znaczenie w majątku, niż ma to miejsce w strefie euro. Ponadto, majątek netto gospodarstw domowych w Polsce jest rozłożony bardziej równomiernie niż przeciętnie w strefie euro. W szczególności nierówności majątkowe dla Polski, mierzone współczynnikiem Giniego, wynoszą 56,8 proc. wobec przeciętnie 68,5 proc. w strefie euro [Bourguinon, 2017].

Biorąc pod uwagę specyfikę polskiej zamożności, warto przyjrzeć się bardziej szczegółowym danym, odnoszącym się do zróżnicowania według grup kwantylowych. Przyjmując założenie, że osoby zamożne znajdują się w grupach kwantylowych dochodów 80-90 proc. i 90-100 proc. należy zauważyć, że poziom ich średniego dochodu jest od 6 do 10 razy większy niż w przypadku gospodarstw pierwszego kwantyla. Z kolei poziom średnich wydatków konsumpcyjnych to odpowiednio od 25-17 proc. ich średnich dochodów (dla dochodów pierwszego kwantyla ten udział wynosi 53 proc.). 
Warto także zauważyć, że szczególnie ostatnia grupa kwantylowa jest silnie zróżnicowana wewnętrznie pod względem otrzymywanego dochodu netto, o czym świadczy niższa mediana dochodu niż w pozostałych grupach kwantylowych (tablica 1). Dwie najwyższe dochodowe grupy kwantylowe różną się także od pozostałych w strukturze posiadanych aktywów finansowych (tablica 2).

Należy nadmienić, że w Polsce nie wykształciła się warstwa społeczna, opierająca swoją zamożność na bogactwie gromadzonym przez dziesiątki lat i dziedziczonym z pokolenia na pokolenie, określana jako „stare pieniądze” (old money). Ogólny poziom zamożności jest znacząco niższy, w związku z czym światowe progi wejścia do grona osób zamożnych muszą być w Polsce obniżone. Instytucje finansowe poza Polską, w segmentacji osób zamożnych uznają osoby dysponujące aktywami płynnymi o wartości powyżej 1 miliona USD, jako High Net Worth Individuals (HNWI). Próg $1 \mathrm{mi}-$ liona USD wolnych aktywów jest poziomem wyjściowym, od którego tworzone są dalsze klasy zamożności, w górę lub w dół. Uwzględniając jednak polskie ograniczenia, można wyróżnić trzy poziomy zamożności: (1) segment HNWI, dyspo- nujący aktywami finansowymi o wartości minimum 1 miliona złotych; (2) segment Affluent o aktywach powyżej 500 tys. zł oraz (3) segment Mass Affluent o zakumulowanych aktywach powyżej 100 tys. zł [Pietrzak, 2012].

Często przytaczaną, a dzięki corocznym badaniom empirycznym ugruntowaną w dyskursie o zamożności Polaków, jest klasyfikacja KPMG oparta na danych z PIT. Autorzy klasyfikacji, za osoby dobrze zarabiające (affluent) uznają osoby $\mathrm{z}$ dochodem brutto powyżej 7,1 tys. zł miesięcznie, za osoby bogate $\mathrm{z}$ dochodem brutto powyżej 20 tys. miesięcznie, a za osoby bardzo bogate te o miesięcznym dochodzie brutto powyżej 50 tys. Jak wynika z raportu opublikowanego w grudniu 2017 r. [KPMG, 2017], liczba zamożnych Polaków (o dochodzie miesięcznym brutto powyżej 7,1 tys. zł) w 2016 roku po raz pierwszy w historii przekroczyła milion osób. Wśród tej grupy 164 tys. podatników osiągnęło miesięczny dochód brutto powyżej 20 tys. zł, w tym 42 tys. Polaków - powyżej 50 tys. zł. Ich łączne dochody netto szacowane są na około $171 \mathrm{mld}$ zł. Uśredniając, dochody przeciętnego zamożnego lub bogatego Polaka wynoszą około 18 tys. zł brutto miesięcznie, czyli ponad cztery średnie krajowe wynagrodzenia.

Tablica 1 Dochody netto a wydatki ogółem i wydatki konsumpcyjne wg grup kwantylowych dochodów netto i majątku netto w 2016 roku

\begin{tabular}{|c|c|c|c|c|c|c|}
\hline \multirow[t]{2}{*}{ Wyszczególnienie } & \multicolumn{2}{|c|}{$\begin{array}{l}\text { dochody netto } \\
\text { (tys. z1) }\end{array}$} & \multicolumn{2}{|c|}{$\begin{array}{c}\text { wydatki ogółem } \\
\text { (tys. zł) }\end{array}$} & \multicolumn{2}{|c|}{$\begin{array}{l}\text { wydatki konsumpcyjne } \\
\text { (tys. z1) }\end{array}$} \\
\hline & mediana & średnia & mediana & średnia & mediana & średnia \\
\hline \multicolumn{7}{|c|}{ dochód netto kwantyle } \\
\hline $0-20 \%$ & 16,0 & 15,3 & 16,2 & 19,0 & 6,6 & 8,0 \\
\hline $20-40 \%$ & 30,3 & 30,7 & 25,6 & 27,8 & 10,8 & 11,6 \\
\hline $40-60 \%$ & 46,6 & 46,5 & 34,8 & 37,1 & 14,4 & 15,4 \\
\hline $60-80 \%$ & 64,3 & 65,0 & 40,3 & 44,7 & 15,6 & 17,8 \\
\hline $80-90 \%$ & 85,9 & 86,7 & 49,0 & 54,4 & 19,5 & 21,3 \\
\hline $90-100 \%$ & 121,9 & 148,8 & 63,2 & 74,5 & 25,2 & 26,7 \\
\hline \multicolumn{7}{|c|}{ majątek netto kwantyle } \\
\hline $0-20 \%$ & 29,7 & 35,5 & 24,3 & 26,8 & 9,6 & 11,0 \\
\hline $20-40 \%$ & 36,1 & 41,6 & 26,8 & 30,7 & 11,9 & 12,6 \\
\hline $40-60 \%$ & 47,4 & 52,5 & 32,7 & 36,0 & 13,1 & 14,9 \\
\hline $60-80 \%$ & 56,2 & 60,9 & 36,7 & 41,6 & 14,4 & 16,9 \\
\hline $80-90 \%$ & 60,9 & 69,2 & 43,4 & 49,4 & 18,0 & 19,8 \\
\hline $90-100 \%$ & 78,0 & 99,6 & 52,9 & 66,9 & 20,4 & 22,8 \\
\hline
\end{tabular}

Źródło: Zasobność gospodarstw domowych w Polsce. Raport z badania 2016 r., NBP, Warszawa 2017, s. 120. 
Tablica 2 Udział aktywów w łącznej wartości aktywów finansowych wg grup gospodarstw domowych w 2016 roku

\begin{tabular}{lr|r|r|r|r|r}
$\begin{array}{l}\text { Dochód netto } \\
\text { kwantyle }\end{array}$ & depozyty & $\begin{array}{r}\text { fundusze } \\
\text { inwestycyjne }\end{array}$ & $\begin{array}{r}\text { obligacje } \\
\text { akcje }\end{array}$ & III filar & inne \\
$0-20 \%$ & 84,5 & 0,2 & 0,2 & 9,0 & 4,1 \\
$20-40 \%$ & 81,6 & 1,8 & 0,7 & 1,1 & 9,3 & 5,6 \\
$40-60 \%$ & 80,0 & 4,7 & 0,5 & 2,3 & 10,9 & 1,7 \\
$60-80 \%$ & 79,6 & 4,0 & 0,6 & 1,3 & 10,2 & 4,3 \\
$80-90 \%$ & 79,4 & 6,3 & 0,3 & 0,9 & 8,5 & 4,6 \\
$90-100 \%$ & 62,2 & 14,1 & 0,5 & 2,9 & 6,5 & 13,8
\end{tabular}

Źródło: Zasobność gospodarstw domowych w Polsce. Raport z badania 2016 r., NBP, Warszawa 2017, s. 105.

Inspiracją do podjętego w 2017 badania empirycznego (Badanie klientów Affluent, IBRiS dla Deutsche Bank, na losowo-kwotowej próbie $\mathrm{N}=1000$ dorosłych Polaków, listopad 2017), było rozpoznanie zachowań finansowych osób bardziej zamożnych niż grupa mass affluent wyznaczona przez KPMG. Celem zespołu badawczego (w składzie również autorka) była, poszerzona o elementy psychograficzne, diagnoza zachowań finansowych osób z dochodem netto powyżej 7500 zł miesięcznie. W badaniu dokonano diagnozy w obszarach: oszczędzania, inwestycji, skłonności do korzystania z kredytów oraz subiektywnych ocen co do przyszłości.

Warto podkreślić, że zadając pytanie o dziesięcioletnią perspektywę postrzegania swojej sytuacji finansowej zdiagnozowano dużą grupę realistów, twierdzących, że myśląc o przyszłości odczuwają lekką niepewność, jednakże nie sądzą, by dotknęły ich większe kłopoty. Grupą o największej negatywnej ocenie swej przyszłości finansowej były osoby obciążone dużymi zobo- wiązaniami finansowymi (np. kredyt hipoteczny). Odnotowano także pokaźną grupe osób skoncentrowanych na teraźniejszości, które $\mathrm{z}$ różnych względów nie zaprzątają sobie głowy myśleniem o swej przyszłości finansowej. Najbezpieczniej czują się osoby w wieku 35-44 lata - aż 40 proc. $z$ nich nie odczuwa żadnych obaw, myśląc o swojej przyszłości finansowej (rys. 2).

Jako drugi ważny obszar diagnozy należy uznać skłonność do oszczędzania. Jak wynika z otrzymanych rozkładów odpowiedzi, poziom środków przeznaczonych na oszczędzanie jest zróżnicowany. Nieco więcej niż co piąty respondent może sobie pozwolić na odkładanie co miesiąc sumy przekraczającej 3000 zł, a niemal identyczny odsetek uznał, że kwota oszczędności mieściłaby się $\mathrm{w}$ przedziale 201-500 zł. Potwierdza to inne obserwacje, że nawyki oszczędzania i inwestowania dopiero się tworzą. Wydaje się, że z czasem, gdy wiedza i doświadczenie tych osób będzie się zwiększać, wzrośnie również liczba wskazań dla kwot oscylujących w środkowych

Rysunek 2 Subiektywne odczucia co do perspektywy przyszłości finansowej wśród Polaków o dochodach powyżej 7500 zł netto na osobę (w \% odpowiedzi)

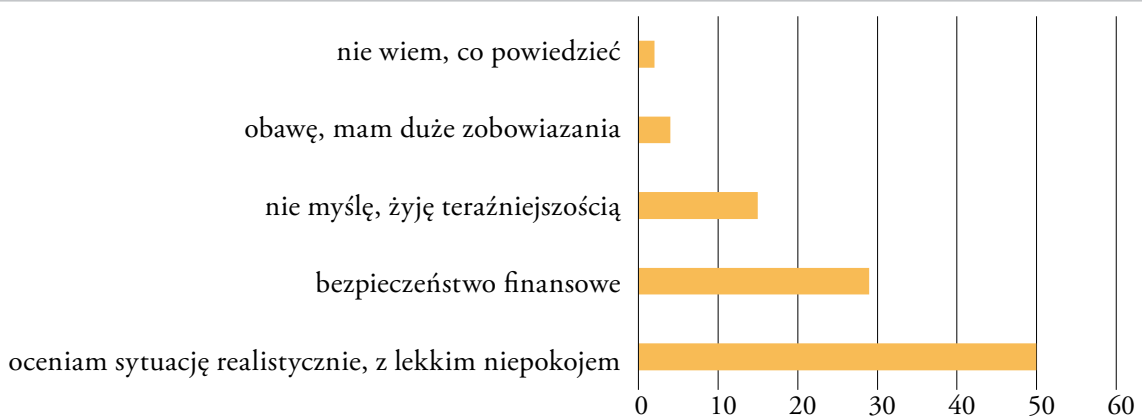

Źródło: Badanie klientów Affluent 2017, IBRiS dla Deutsche Bank, na losowo-kwotowej próbie N=1000 dorosłych Polaków, listopad 2017. 
Rysunek 3 Skłonność do systematycznego odkładania miesięcznych kwot przez Polaków o dochodach powyżej 7500 zł netto na osobę (w \% odpowiedzi)

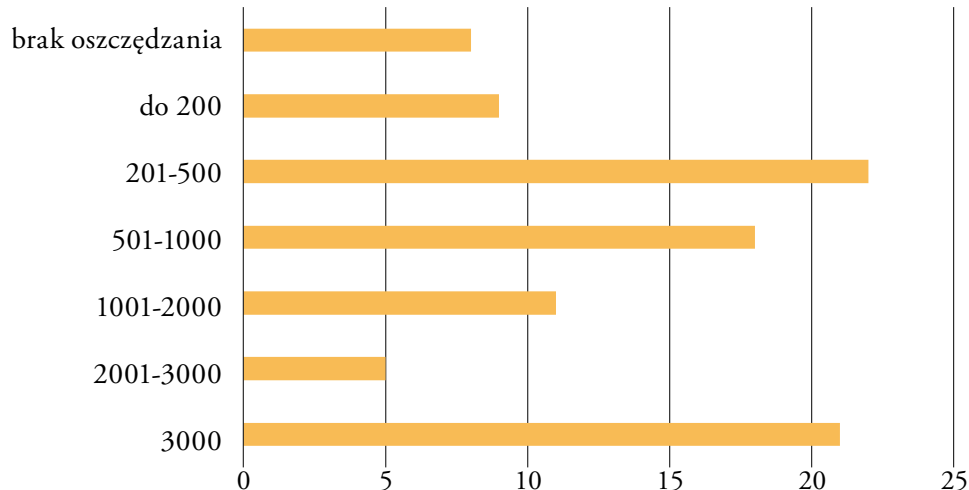

Źródło: Badanie klientów Affluent 2017, IBRiS dla Deutsche Bank, na losowo-kwotowej próbie N=1000 dorosłych Polaków, listopad 2017.

przedziałach (czyli 1000-2000 zł). Interesującym jest fakt, ze kobiety są skłonne częściej oszczędzać powyżej 3000 zł miesięcznie (stwierdziło tak 26 proc. respondentek) niż mężczyźni - 18 proc. Jako niepokojące należy uznać deklaracje o braku oszczędzania, czy to systematycznego czy też incydentalnego - wskazało tak aż 21 proc. respondentów (rys. 3).

Interesującym wątkiem badania była próba scharakteryzowania finansowej poduszki bezpieczeństwa. Chodziło o uchwycenie realnego poziomu zgromadzonych aktywów, które pozwalałyby myśleć o spokojnej przyszłości. Na podstawie otrzymanych odpowiedzi wyznaczono wielkości graniczne: minimalną do 10 tysięcy zł. i maksymalną powyżej 500 tysięcy zł. Tak duża rozpiętość kwot świadczy o zróżnicowanych potrzebach i aspiracjach polskich zamożnych respon- dentów. Należy podkreślić, że mężczyźni znacznie częściej wskazywali na wyższe kwoty, które zagwarantowałyby im poczucie bezpieczeństwa, kobiety natomiast podchodziły do tej kwestii bardziej zachowawczo - 41 proc. kobiet zadowoliłoby się kwotą 100 tysięcy. Z kolei poduszka finansowa o wartości przekraczającej sumę 500 tys. pozwoliłaby czuć się pewnie 32 proc. mężczyzn (rys. 4).

Jeżeli chodzi o sposoby budowania kapitału, to 30 proc. respondentów odkłada nadwyżki finansowe na koncie oszczędnościowym. Niewiele mniej, bo 27 proc., w tym celu wykorzystuje lokaty bankowe. Na trzecim miejscu wśród najpopularniejszych metod służących budowaniu kapitału uplasowały się inwestycje w nieruchomości - wskazało na nie 17 proc. respondentów. Wśród innych, rzadziej wybieranych form oszczędzania czy in-

Rysunek 4 Oszczędzanie a poczucie bezpieczeństwa - „poduszka finansowa” wśród Polaków o dochodach powyżej 7500 zł netto na osobę (w \% odpowiedzi)

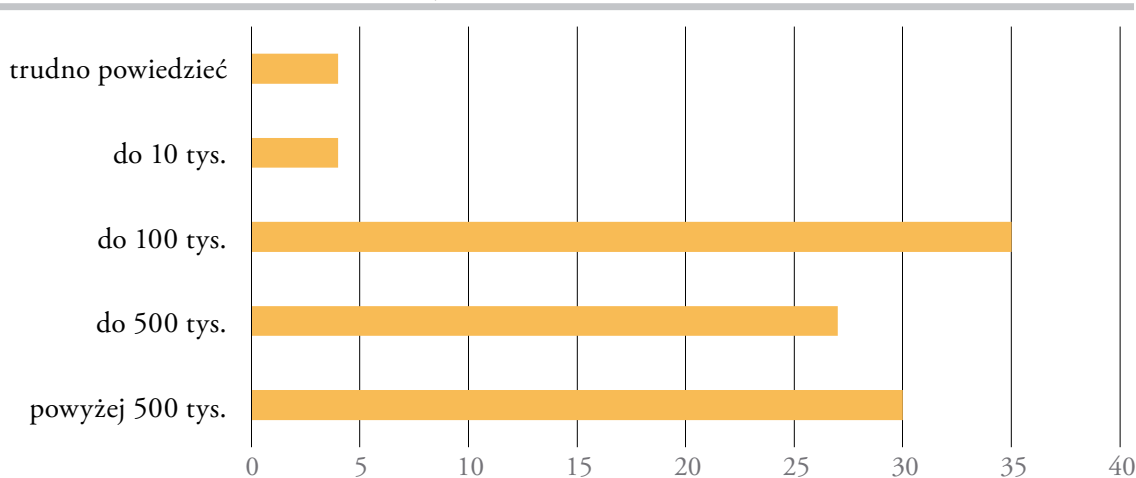

Źródło: Badanie klientów Affluent 2017, IBRiS dla Deutsche Bank, na losowo-kwotowej próbie N=1000 dorosłych Polaków, listopad 2017. 
Rysunek 5 Sposoby budowania kapitału wśród Polaków o dochodach powyżej 7500 zł netto na osobę ( $w \%$ odpowiedzi)

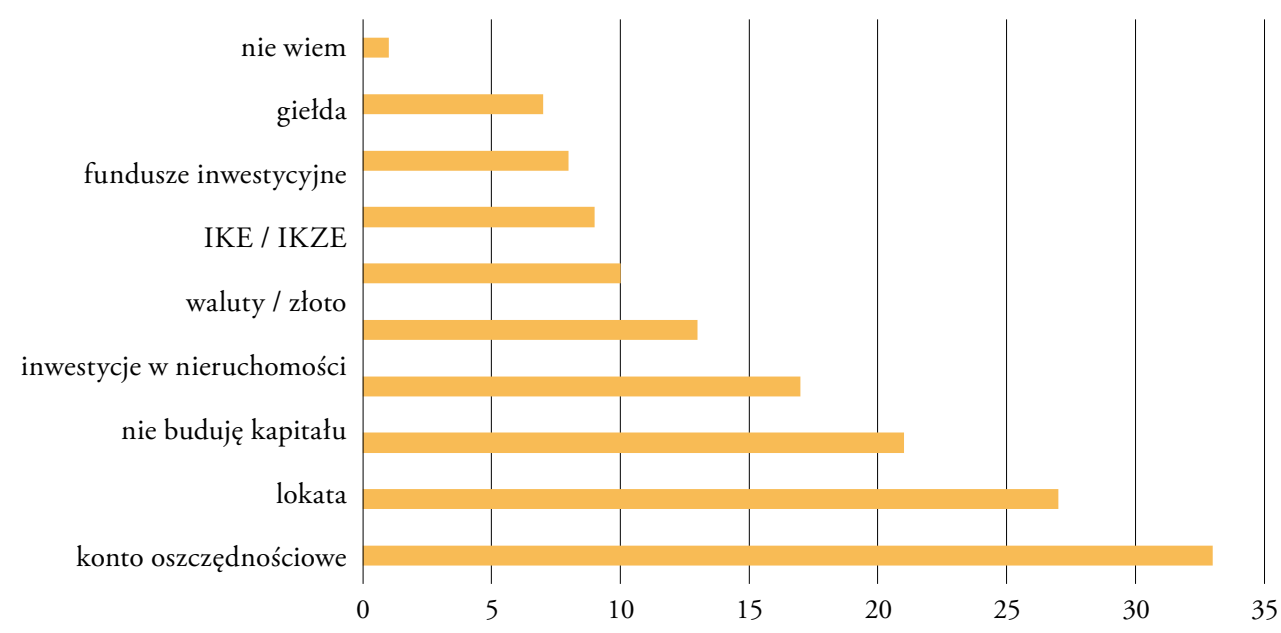

Źródło: Badanie klientów affluent 2017, IBRiS dla Deutsche Bank, na losowo-kwotowej próbie N=1000 dorosłych Polaków, listopad 2017.

westowania, ankietowani wskazali na waluty i kruszce (13 proc.), IKE i IKZE (10 proc.), plan systematycznego oszczędzania (9 proc.), fundusze inwestycyjne (8 proc.) oraz inwestowanie na giełdzie (7 proc.).

\section{Zakończenie}

Z przeprowadzonego badania wyłania się interesujący obraz polskiego segmentu affluent. Są to przedstawiciele polskiej klasy średniej, wewnętrznie zróżnicowanej według grup społeczno-zawodowych - także w takich aspektach jak skłonność do samodzielnego podejmowana decyzji inwestycyjnych, dywersyfikacji sposobów budowania majątku, celów oszczędzania czy też preferowanych cech produktów bankowych. Polski segment affluent na pewno odróżnia się od ogólnej populacji Polaków pod względem częstszej skłonności budowania kapitału na przyszłość, choćby z pojawiających się nadwyżek finansowych w tzw. funduszu swobodnej decyzji. Nie da się jednak ukryć, że nadal funkcjonują $\mathrm{w}$ badanej grupie preferencje zachowawcze - preferowane formy „bogacenia” to konto oszczędnościowe czy lokaty. Ponadto, widzimy międzypokoleniową transmisję przekonań z początków polskiego kapitalizmu (lub nawet wcześniejszych), że dobrą formą akumulowa- nia kapitału są nieruchomości (niestety, bez wskazania na tzw. nieruchomości inwestycyjne) oraz złoto. Jednym słowem - występuje powszechny prymat bezpieczeństwa nad ryzykiem.

Segment affluent to ponadprzeciętna (w stosunku do ogółu Polaków) reprezentacja inwestorów lub uczestników funduszy inwestycyjnych - to mimo wszystko osoby o większej świadomości ekonomicznej, a także wiedzy o mechanizmach gospodarki rynkowej. Należy pamiętać także o tym, że ryzyko poniesienia straty, a przede wszystkim niechęć do opłat, jest ważną kwestią przy ich zachowaniach inwestycyjnych.

Budowanie kapitału jest determinowane nie tylko poziomem przychodów, ale także płcią - kobiety ewidentnie stawiają na zachowania bezpieczniejsze i dające gwarancję ochrony kapitału, nie stronią od fachowej porady i ewentualnej pomocy. Z kolei domeną mężczyzn jest większa skłonność do podejmowania ryzyka niosącego nie tylko zagrożenie popełnienia błędu, ale także i większe korzyści ekonomiczne. Sam proces podejmowania decyzji inwestycyjnych jest także interesujący. $\mathrm{U}$ mężczyzn jest typowym działaniem „liniowym”, zorientowanym na szybkie osiągnięcie celu. Z kolei u kobiet jest on 
wielowątkowy, często tzw. „zawracający” do punktu wyjścia pod wpływem nowych informacji - dotyczy to szczególnie sytuacji zbierania informacji o możliwościach inwestycyjnych oraz porównań alternatyw wyboru. Kobiety częściej szukają psychologicznego potwierdzenia słuszności samego wyboru inwestycyjnego (w badaniu zdiagnozowano ważną rolę doradcy finansowego).

$\mathrm{Na}$ badanych zamożnych Polaków można spojrzeć jak na podgrupy polskiej klasy średniej: klasę inwestujących budowniczych kapitatu i klasę konsumująco-oszczędzająca. W klasie budowniczych kapitatu widzimy, jak dużą wagę przywiązuje się do samodzielności decyzji inwestycyjnych. Choć maleje ona $\mathrm{z}$ wiekiem (młodzi mają wysokie zdolności wyszukiwania informacji z wielu źródeł, osoby starsze mogą mieć więcej roztropności w procesach decyzji inwestycyjnych), to i tak jest wyższa od całej populacji dorosłych Polaków. Widzimy także ciekawe przekroje zawodowe, w których przedstawiciele branży IT, handlu, pracownicy usług finansowych oraz inżynierowie i architekci - to grupy najbardziej zdygitalizowane w procesie decyzyjnym dotyczącym inwestycji. Druga grupa, czyli klasa konsumująco-oszczędzająca, jest rozdarta pomiędzy pragnienie budowania kapitału i odkładanie gratyfikacji na przyszłość a pokusy konsumpcyjne. W otrzymanych wynikach zastanawiającą kwestią jest duże zróżnicowanie deklarowanych kwot możliwych do oszczędzania. Skoro prawie jedna piąta badanych mówi o kwocie ponad 3000 zł miesięcznie, to powstaje pytanie, jak można je dobrze zagospodarować za pomocą specjalnych produktów bankowych dla tej grupy. Szczególnie, że profile zawodów najbardziej skłonnych do odkładania tej kwoty są dosyć zróżnicowane - mamy tam zarówno pracowników najemnych jak i wolne zawody - handel, branża IT, pracownicy usług finansowych, lekarze, prawnicy oraz inżyniero- wie i architekci. Ponadto, segment affluent nie opiera się pokusom ewidentnie konsumpcyjnym, o czym świadczą deklaracje przeznaczania kredytu gotówkowego: wakacje, samochód, remont mieszkania czy zabiegi medyczne. To pokazuje nadal utrzymującą się aspiracyjność konsumpcyjną i wyczulenie na tzw. statusowe kody konsumpcji. Jest to grupa o dużym poczuciu bezpieczeństwa finansowego, bez większych obaw co do przyszłości. To też tłumaczy umiejętność wyobrażenia sobie granicznej kwoty dającej poczucie posiadania poduszki finansowej. Wymieniana przez jedną trzecią kwota powyżej 500 tys. zł jest dowodem na bardzo duże możliwości rozbudzania potrzeby umiejętnego mnożenia kapitału, by taką kwotę samodzielnie osiągnąć.

Grupa zamożnych Polaków ma dużo doświadczenia na rynku, a także ukształtowanych jawnych postaw wynikających z zachowań homo oeconomicus (wolą niskie opłaty, niską a najlepiej brak prowizji, darmowe wypłaty z bankomatów itp.). Każda zmiana i podnoszenie opłat spotykają się z jej niechęcią, bardziej z powodu odebrania przywileju niż samej dotkliwości wydatku. Tego rodzaju postrzeganie opłat jako straty, wpływa na kształtowanie utajonych negatywnych postaw konsumenckich. Jest to grupa o dużym potencjale, wynikającym nie tylko z deklaracji możliwych do oszczędzania kwot $\mathrm{w}$ miesiącu, ale także $\mathrm{z}$ powodu aspiracji posiadania określonych kwot finansowych dających poczucie bezpieczeństwa finansowego (tzw. poduszki finansowej). Jest to grupa $\mathrm{z}$ wieloma nieuświadomionymi potrzebami w ramach pomnażania finansów osobistych. Choć w budowaniu swojej kariery zawodowej jest bez wątpienia bardzo kreatywna i przedsiębiorcza, to tych cech nie do końca widzimy w podejściu do zarządzana własnym majątkiem. Więcej jest szukania wygody i „taniego" poczucia bezpieczeństwa niż świadomych, często bardziej ryzykow- 
nych, ale ze społecznego punktu widzenia wzorcotwórczych zachowań. Czasami można odnieść wrażenie, że ciężko zapracowane pieniądze nie cieszą się wystarczającą estymą i szacunkiem, ponieważ nie są umiejętnie pomnażane.

Należy zauważyć, że rozpoznany obszar zachowań finansowych osób zamożnych może być przydatny w wypracowaniu i rozpowszechnianiu wzorcotwórczych modeli gospodarowania pieniędzmi wśród mniej zamożnych Polaków. Wynika to z trzech istotnych przesłanek. Po pierwsze, chodzi o problem wiedzy ekonomicznej. W okresie nadganiania dystansu cywilizacyjnego nie przywiązywano wagi do edukacji ekonomicznej. Obserwacja i przejmowanie zachowań osób zamożniejszych może wpłynąć na podnoszenie ogólnej wiedzy ekonomicznej. Po drugie, istnieje problem „dziedziczonego" społecznie podejścia do gromadzenia majątku. Nadal wśród Polaków brakuje "grupy odniesienia” w dziedzinie budowania majątku i bogactwa, która byłaby wzorem do naśladowania. Po zawierusze wojennej, przez blisko pięć dekad akumulowanie majątku było zarezerwowane dla wybranych grup lojalnych władzy (więc od razu stygmatyzowane), piętnowane („tzw. prywaciarze”) bądź wprost nielegalne (szara strefa). Otwarte i legalne gromadzenie pieniędzy jest stosunkowo czymś nowym, co wymaga zaangażowania i wiedzy oraz umiejętności kalkulowa- nia ryzyka. Jeżeli ryzyko jest „nieobłaskawione” to budzi lęki, które wpływają na poczucie własnej sprawczości. A właśnie z poczuciem sprawczości mamy jako Polacy problem. Jest ono bardziej narzucane warunkami zewnętrznymi dla jednostki - np. przymus mody, stylów życia, a nie wynika z poczucia własnej wartości. Ponadto, trzeba rozwiązać problem podejścia do zapewnienia sobie pomyślności. Przez wiele lat (wojna, okres gospodarki centralnej) łatwiej było funkcjonować ze świadomością jakoś to będzie, które miało wpisany pozytywny ładunek emocjonalny. Potem zaczęło przechodzić w jakoś to będzie wynikające $\mathrm{z}$ przerzucenia odpowiedzialności i rozleniwienia, szczególnie, że gwarantem tego bezpieczeństwa było siłą rzeczy państwo. Zawód w tej kwestii z powodu dyskusyjnych ruchów z OFE czy losu „frankowiczów”, to miejsce na tworzenie w społecznej świadomości imperatywu indywidualnej odpowiedzialności za swój los. Nie jest to proste i łatwe, tym bardziej, że wymaga samoorganizacji, narzucenia sobie ram funkcjonowania i systematyczności. Poza tym, taka cecha jak „roztropność” ekonomiczna nie cieszy się zbytnią estymą. Nie pomagają temu sygnały z otoczenia rynkowego - w stylu „kupuj więcej, posiadaj, pożycz pieniądze aby cieszyć się kolejnym zakupem”. Dopóki nie odwrócimy prymatu potrzeb nad ostrożnością i roztropnością ekonomiczną - będziemy mieli grupy konsumentów o niepewnej przyszłości.

\section{Bibliografia:}

1. Bearden W., Netemeyer R., Teel J. [1989], Measurement of Consumer Susceptibility to Interpersonal Influence, "Journal of Consumer Research", Vol. 15.

2. Bombol M. (red.) [2012], Badania polskiej klasy wyższej. Problemy. Diagnozy. Dylematy, SHG, Warszawa.

3. Bourguinon F. [2017], World changes in inequality: an overview of facts, causes, consequences and policies, BIS Working Papers, no 654, August.

4. Burgiel A. [2005], Znaczenie naśladownictwa i wptywów spotecznych w zachowaniach konsumentów, Akademia Ekonomiczna, Katowice.

5. Duesenberry J.S. [1952], Income, saving and the theory of consumer behavior, Cambridge, Mass., Harvard University Press. 
6. Engelberg L. [2007], Money obsession, social adjustment and economic risk perception, "The Journal of Socio Economics", Vol. 36.

7. Furnham A. [1996], Attitudinal correlates and demographic predictors of monetary beliefs and behaviours, "Journal of Organizational Behavior", Vol. 17.

8. Hayhoe C.R, Leach L., Turner P.R. [1999], Discriminating the number of credit cards held by college students using credit and money attitudes, "Journal of Economic Psychology", Vol. 20.

9. Kieżel E. [2003], Zachowanie konsumentów - determinanty, racjonalność, Akademia Ekonomiczna, Katowice.

10. KPMG [2017], Rynek dóbr luksusowych w Polce. Edycja 2017, KPMG, Warszawa.

11. Maison D. [2013], Polak wświecie finansów, O psychologicznych uwarunkowaniach zachowań ekonomicznych Polaków, Warszawa, Wydawnictwo Naukowe PWN.

12. Merton R. [1957], Social theory and social structure, New York, The Free Press.

13. NBP [2017], Zasobność gospodarstw domowych w Polsce. Raport z badania 2016 r., NBP, Warszawa.

14. Newcomb Th., Turner R., Converse Ph. [1965], Psychologia spoteczna, Warszawa, PWN.

15. Shafer A.B. [2000], Mediation of the Big Five's effect on career decision making by the life task dimensions and on the money attitudes by materialism, "Personality and Individual Differences", Vol. 28.

16. Szlendak T., Pietrowicz K. (red.) [2007], Rozkoszna zaraza. O rządach mody w kulturze konsumpcji, Uniwersytet Wrocławski, Wrocław.

17. Wyrwicka W. [2001], Naśladownictwo w zachowaniu się ludzi i zwierząt, Warszawa, Wydawnictwo Naukowe PWN

Prof. dr hab. Małgorzata Bombol, Instytut Rynków i Konkurencji, Kolegium Nauk o Przedsiębiorstwie, Szkoła Główna Handlowa w Warszawie. 